\title{
Preliminary References under EAC Law
}

\author{
Emmanuel Ugirashebuja
}

It was envisaged by the drafters of the Treaty establishing the East African Community (EAC Treaty) that the responsibility of applying its provisions belonged concurrently to the national courts and the East African Court of Justice (EACJ). With this responsibility, a potential challenge of ensuring uniform application of the Treaty was envisioned. In order to avoid the likely possibility of inconsistency in the application of Community law, the EAC Treaty embedded a procedure of preliminary rulings. It should be noted that such a procedure had been earlier adopted in the European Union, and there has considerably enhanced the uniform application of EU law in the European setting. ${ }^{1}$ Article 34 of the EAC Treaty establishes a procedure which enables domestic courts of EAC Partner States to refer to the EACJ questions on Community law which would help them to arrive at a judgment in a substantive case before them. It provides as follows:

Where a question is raised before any court or tribunal of a Partner State concerning the interpretation or application of the provisions of this Treaty or validity of the regulations, directives, decisions or actions of the Community, that court or tribunal shall, if it considers that a ruling on the question is necessary to enable it to give judgment, request the Court to give a preliminary ruling on the question.

The following sections will discuss Article 34 of the EAC Treaty in the light of its practical applicability. The first section reviews the standing of national courts and tribunals in the context of the preliminary reference procedure. The second section analyzes the obligation of national courts to refer questions for preliminary rulings. The third section reviews whether there is an obligation on the part of the EACJ to provide an answer in the form of a preliminary ruling to all references made by national courts. The fourth section discusses the nature and effect of the preliminary ruling made by the EACJ. Finally, the fifth

1 See EU Chapter 8 for an analysis of this procedure under EU law and the crucial role it played in European integration.

(C) EMMANUEL UGIRASHEBUJA, 2017 | DOI 10.1163/9789004322073_016

This is an open access chapter distributed under the terms of the CC-BY-NC License. $\cdot$ Ugirashebuja - 9789004322073 
section will review the relationship between the national courts and the EACJ in light of the established procedure of preliminary reference.

\subsection{Standing of National Courts and Tribunals}

National courts and tribunals do not explicitly feature in the judicial architecture of the Community. The only reference to national courts in the Treaty appears in Article 34 of the EAC Treaty establishing the preliminary reference procedure. However, the national courts and tribunals are vital parts of the Community to the extent that they directly apply Community law to the cases before them where relevant. In East African Law Society v. the Secretary General of the East African Community (2013), the First Instance Division of the EACJ held that:

As Partner States, by virtue of their being the main users of the Common Market Protocol on a daily basis, it would be absurd and impractical if their national courts had no jurisdiction over disputes arising out of implementation of the Protocol. Indeed, Community law would be helpless if it did not provide for the right of individuals to invoke it before national courts. ${ }^{2}$

This view of the First Instance Division was adopted by the Appellate Division in Tom Kyahurwenda (2015) when it stated:

This Court agrees with the postulation of the law by the First Instance Division of this Court that it would be absurd if national courts and tribunals were to be excluded from the application of Treaty provisions should the occasion arise before them. ${ }^{3}$

2 Case No. 1 of 2011 East African Law Society vs. the Secretary General of the East African Community [2013] (EACJ, 2013) 28. The First Instance Division's view was by Van Gend Loos where the ECJ held that: "[t] he fact that Article 169 and 170 of the EEC Treaty enable the Commission and the Member States to bring before the Court a State which has not fulfilled its obligations does not deprive individuals of the right to plead the same obligations, should the occasion arise, before a national court", see Case 26/62 Van Gend Loos [1963] ECR I.

3 Case Stated No. 1 of 2014 Attorney General of Uganda vs. Tom Kyahurwenda [2015] (EACJ, 2015) [54]. 
The starting point for any preliminary reference procedure lies with the question which national courts or tribunals are entitled to ask a question to the EACJ.

Article 34 of the Treaty provides that "where a question is raised before any court or tribunal of a Partner State concerning the interpretation or application of the provisions of this Treaty or the validity of the regulations, directives, decisions or actions of the Community, that court or tribunal shall...". The crucial point is that a question has to be posed by "any court or tribunal" and not any other entity. In the quest to determine what a "court or tribunal" is, the EACJ, in the preliminary ruling on questions posed by the High Court of the Republic of Uganda, drew inspiration from the jurisprudence established by the Court of Justice of the European Union (CJEU) in the Pretore di Salò v. Persons unknown. ${ }^{4}$ In this case, the CJEU held the following:

The Court has jurisdiction to reply to a request for a preliminary ruling if that request emanates from a court or tribunal which has acted in the general framework of its task of judging, independently and in accordance with the law, cases coming within the jurisdiction conferred on it by law, even though certain functions of that court or tribunal in the proceedings which gave rise to the reference for a preliminary ruling are not, strictly speaking, of a judicial nature. ${ }^{5}$

Inspired by this landmark case, the EACJ held that:

... for a national entity to be considered a "court or tribunal" for purposes of preliminary reference, the entity should possess the following attributes: established by law; have permanent existence; endowed with compulsory jurisdiction; have ability to entertain procedures inter partes; apply rules of law; and, be endowed with functional independence. ${ }^{6}$

Any entity which does not fulfil these attributes is not a court or tribunal in the perspective of Article 34 of the EAC Treaty. This would imply that certain tribunals such as arbitral tribunals; commissions of inquiry or tribunals fully controlled by the executive or the legislative arms of government; ad-hoc

4 Case 14/86, Pretore di Salò v Persons unknown [1987] ECR 2545. See further on the EU system EU Chapter 8.

5 Case 14/86 Pretore di Salò v Persons unknown [1987] ECR 2545 [7].

6 Tom Kyahurwenda [40]. 
tribunals; prosecution authorities; and national competition authorities do not have standing for purposes of referring questions to the EACJ.

\subsection{Obligation of a National Court to Refer to the EACJ}

This section inquires whether national courts are under an obligation to refer questions to the EACJ and the extent of such an obligation. In Tom Kyahurwenda, the Partner States made different contentions regarding the interpretation of Article 34 of the Treaty in as far as the obligation of national courts to refer cases is concerned.

The Republic of Uganda contended that the interpretation of the Treaty was a prerogative of the EACJ and that consequently, national courts, at all levels, were barred from interpreting the Treaty. Uganda argued that the sole purpose of Article 34 was to allow national courts to entertain matters of enforcement of the Treaty, but not its interpretation, which squarely fell under the sole purview of the EACJ. The United Republic of Tanzania, held a similar view. The Republic of Kenya, on her part, argued that, in general terms, without looking at each and every specific Article, the Treaty is justiciable before the national courts. The argument of Kenya essentially meant that the EACJ and the national courts have concurrent jurisdiction on the interpretation of the Treaty, and that the discretion to refer a question to the EACJ lies with a national court when faced with a case involving Community law. The Secretary General of the EAC held a similar view to that of Kenya on the basis that the wording of Article 34 (" $\ldots$ if it considers that a ruling on the question of interpretation or application of the Treaty is necessary to enable it to give judgment"), should be construed to mean that Partner States were endowed with the discretion whether or not to refer a question to the EACJ.

In order to determine the extent of the obligation of national courts to make preliminary reference, the EACJ reviewed the wording of Article 34 of the Treaty, in Tom Kyahurwenda. ${ }^{7}$ The EACJ held that:

Article 34 of the Treaty further provides that where a court or tribunal is faced with "... the interpretation or application of the provisions of this Treaty or the validity of the regulations, directives, decisions or actions of the Community, that court or tribunal shall if it considers that a ruling

7 It is important to note here that the EACJ in this case resorted to the canons of interpretation established by the Vienna Convention on the Law of Treaties, in particular, Articles 31 and $3^{2 .}$ See, Tom Kyahurwenda [33]. 
on the question is necessary to enable it to give judgment, request the Court to give a preliminary ruling on the matter". The provision uses the emphatic word "shall". In the general scheme of legal drafting, the use of the word "shall" would presuppose that when the national courts or tribunals are faced with a question of interpretation, application or validity, they have no option, but to refer the matter to this Court. ${ }^{8}$

The EACJ's ruling made it clear that it possesses the monopoly of interpretation of the EAC Treaty. In other words, when any national court is faced with the question of interpreting the Treaty, it has no choice but to refer the question to the EACJ.

In answering to the apparent discretion of national courts in Article 34, the EACJ noted that:

... the discretion afforded to national courts by Article 34 is the discretion to refer or not to refer a question of interpretation to this Court. However, the condition precedent to the exercise of this discretion is this: "if the national court or tribunal considers that a ruling on the question is necessary to enable it to make a judgment..." Once a national court or tribunal considers an interpretation to be necessary, then it has no option but to refer the question to this Court. Hence, the discretion is narrow. It is confined to determining whether or not a ruling on the question is necessary to enable the court to make its judgment. ${ }^{9}$

In determining the parameters of the discretion of national courts to determine the necessity to refer a question, the Court noted that the discretion was, "in the great majority of cases," limited to: cases where the Community law is not relevant to the matter before national courts ("an irrelevant question"); cases where the EACJ has already clarified the point of law in its previous cases ("acte eclairé"); and, instances where the interpretation of the Community law is obvious ("acte clair"). ${ }^{10}$ Simply put, under Article 34 of the EAC Treaty, a reference must be made unless the national court has recognized any of the above reasons for not doing so. ${ }^{11}$

In Tom Kyahurwenda, the EACJ distinguished the discretion endowed to the national courts by the Treaty to refer or not to refer a question for interpretation

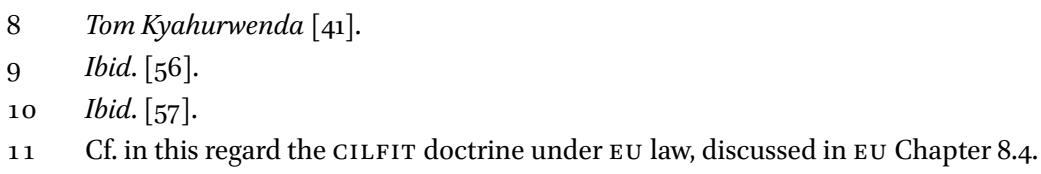


from the obligation to refer where the subject matter involves invalidation of the regulations, directives, decisions or actions of the Community. The EACJ stated that it would be "disastrous were national courts and tribunals permitted to declare Community Acts, regulations, directives and actions invalid in the absence of a ruling to that effect by the East African Court of Justice". ${ }^{2}$ It is very clear from this that the EACJ has exclusive powers to invalidate any acts, regulations, directives and actions of the Community and therefore, if such a question arises, a national court is under an obligation to refer to the EACJ.

\subsection{Obligation of the EACJ to Provide an Answer}

From the outset, it is paramount to note that the role of the EACJ in a preliminary ruling is to interpret Community law and determine the validity of Acts of the Community. The Court cannot apply Community law to the facts of the case at hand. Consequently, the function of the EACJ in a preliminary ruling is to provide an abstract interpretation of Community law. It is also important to mention that the EACJ cannot interpret or apply national law. Hence, the Court can decline to answer a question from a national court where it is called upon to apply Community law to a case before that national court or to interpret or apply national laws.

As a vital condition precedent for the EACJ to provide an answer, there has to be a live case before a national court requesting a preliminary ruling. The rationale for this is that the ultimate purpose of a preliminary reference is to enable a national court to resolve a matter before it. The EACJ will therefore reject a reference where the questions referred are hypothetical in nature. In Alcon International Limited, even though it did not come through the channel of preliminary reference, the EACJ adopted the well-known principle of mootness or academic adventure. The Court observed that "the raison d'être of Courts of Justice is to give binding decisions to live disputes..." and that in the absence of a live dispute, they may not engage in a "futile and vain exposition of the law".13 The same outcome would be adopted in the event that a preliminary reference is moot or academic. ${ }^{14}$

It is also important that the question referred should be relevant to the case pending before the national court. Otherwise, the question would suffer the

\footnotetext{
12 Ibid. [48].

13 Appeal No. 3 of 2013 Alcon International Limited vs. Standard Chartered Bank of Uganda and 2 Others [2015] (EACJ, 2015) [99].

14 See the similar approach under EU law as set out in EU Chapter 8.5.
} 
same fate as a moot or academic question. In order for the EACJ to be able to deliver a relevant and useful preliminary ruling or to determine whether the question is moot or academic, the reference should contain detailed relevant information about the factual background to the case and/or the relevant provisions of the national law in question.

Once the conditions of a live case and relevance of the question to the case at hand are fulfilled, then the Court is under the obligation of giving an answer in the form of a preliminary ruling. Article 35(1) of the Treaty is very clear in as far as the obligation is concerned. It provides: "The Court [the EACJ] shall consider and determine every reference made to it pursuant to this Treaty in accordance with the rules of the Court and shall deliver in public, a reasoned judgment". The emphatic use of the word "shall" in delivering a judgment would suggest that once a given reference including a preliminary reference satisfies the conditions established by the Rules of Procedure of the EACJ, then the Court is under the obligation to deliver a reasoned judgment.

\subsection{The Nature and Effect of the Preliminary Ruling}

As discussed above, a preliminary ruling is by its very nature a ruling of the Court and it has all the attributes and effects of any other ruling by the EACJ. The rulings and judgments of the EACJ, as one of the organs of the Community, are binding and take precedence over any national organ of the Partner States. To this end, Article 8(4) of the EAC Treaty provides: "Community organs [including the EACJ], institutions and laws shall take precedence over similar national ones on matters pertaining to the implementation of this Treaty". In an even more specific provision to the rulings of the Court, Article 38(3) of the Treaty provides: "A Partner State or Council shall take, without delay, the measures required to implement a judgment of the Court". Implementation of a judgment of the Court would include the application of a preliminary ruling of the EACJ by both the court which asked the question and also all other courts in EAC Partner States in similar cases. In other words, once the EACJ delivers a preliminary ruling, it is binding on all courts in the Community. To emphasize the binding nature of a preliminary ruling, the EACJ in Tom Kyahurwenda held that:

This Court deems it apposite to draw attention to two points of fundamental importance. The first fundamental point is that this Court's preliminary ruling is binding on the national court or tribunal which has sought a preliminary ruling. The second fundamental point is that a 
preliminary ruling is binding erga omnes (towards all). It is erga omnes in the sense that it is binding on all national courts and tribunals in all Partner States of the Community. ${ }^{15}$

To put it otherwise, the court that made the reference and all other courts in the EAC Partner States that encounter the same subject matter are bound by the operative part of the preliminary ruling. The Tom Kyaruhwenda preliminary ruling implies that the ruling is capable of applying retrospectively since it is binding on all national courts. Furthermore, the ruling establishes a precedent which the EACJ will itself follow in similar matters.

It is also important to note that in Tom Kyaruhwenda the EACJ decided that since the ruling was a step towards the resolution of the dispute before the Ugandan Court, "the decision as to costs is the matter for that Court [High Court of Uganda] to pronounce in the context of the proceedings before it".16 As to the costs incurred by the Secretary General and the Partner States in submitting their observations in matters of preliminary references, the EACJ opined that they are not recoverable. ${ }^{17}$

\subsection{The Relationship between the National Courts and the EACJ}

As previously discussed, the EAC Treaty envisages no particular relationship between national courts and the EACJ, except for Article 34 which creates the procedure of preliminary references, detailed throughout this chapter. The EACJ has so far entertained one preliminary reference in its fifteen years of existence. However, the importance of the preliminary reference procedure should not be gauged from the number of cases referred but the potential it has to significantly impact on the process of the EAC integration through developing Community law.

The success of the preliminary reference procedure lies in the cooperation, or what is widely referred to as a "judicial dialogue" between the EACJ and the national courts. The preliminary ruling procedure promotes preservation of legal unity through uniform interpretation and application of Community law. In stressing the importance of the "judicial dialogue" through the preliminary reference, the EACJ in Tom Kyahurwenda stated:

\footnotetext{
15 Tom Kyaruhwenda [58].

16 Tom Kyaruhwenda [76].

17 Tom Kyaruhwenda [76].
} 
It is of utmost importance to understand the significance of the preliminary ruling procedure. The procedure is the keystone of the arch that ensures that the Treaty retains its Community character and is interpreted and applied uniformly with the objective of its provisions having the same effect in similar matters in all the Partner States of the East African Community. In the absence of this procedure, it is possible that legions of interpretation of the same Treaty would emerge drifting hither and thither, aiming at nothing. This would at best create a state of confusion and uncertainty in the interpretation and application of the Treaty; and at worst, ignite an uncontrolled crisis which would destabilise the integration process. The situation could even be more disastrous were national courts and tribunals permitted to declare Community Acts, regulations, directives and actions invalid in the absence of a ruling to that effect by the East African Court of Justice. ${ }^{18}$

National judges apply Community law as well as the interpretation of the law through preliminary rulings manufactured by the EACJ as part of the Partner States' national laws. The procedure ensures that individual rights under Community law which have been infringed are legally redressed. Preliminary references have created a forum of cooperation between national judges and EACJ judges in resolution of domestic cases with aspects of Community law and further development of Community law.

Even though, as discussed earlier, the importance of the instrument of preliminary reference lies in the appropriate division of labor in the development and application of Community law, it is nonetheless imperative to analyze why the instrument has not generated a voluminous amount of workload for the EACJ as it has in the CJEU. ${ }^{19}$ The number of all the references filed in the EACJ is way below those filed annually at the CJEU. It should be noted that, with the exception of the one preliminary reference and the two advisory opinions, the rest of the cases filed in the EACJ have been by persons (both natural and legal).

18 Ibid. [48].

19 In the ECJ, preliminary reference accounts for over 50\% of the Court's workload. In 2014 alone, the total number of references were 622 . See further Eu Chapter 8 . Whereas in the lifespan of the EACJ today, it has received two references and delivered one preliminary ruling. 
The EAC Treaty affords individuals the right to directly file cases with the $\mathrm{EACJ},{ }^{20}$ whereas such a right of direct action by persons is permitted only exceptionally before the $\mathrm{CJEU} .{ }^{21}$ It would be a viable assumption that individuals might have opted to use the route of direct action under the EACJ setting and this would explain why preliminary references are very rare as opposed to the CJEU where direct action is restricted.

Another possible explanation of why the preliminary reference procedure has not been used is the absence of knowledge of its existence by both the residents of the Community and judges of national courts. The EACJ has sought to rectify this problem and has embarked on a sensitization program of judges through actively organizing and being part of conferences in the Partner States.

The importance of the preliminary reference instrument as a source of dialogue between national judges and the EACJ cannot be stressed further. With the Court having delivered its first preliminary ruling, it is hoped that it will open the way for many more preliminary references in the future with a view of developing and promoting cohesion of Community law and deeper integration.

20 Article 30(1) of the EAC Treaty provides: "Subject to the provisions of Article 27 of this Treaty, any person who is a resident in a Partner State may refer for determination by the Court, the legality of any Act, regulation, directive, decision or action of a Partner State, or institution of the Community on the ground that such Act, regulation, directive, decision or action is unlawful or is an infringement of the provisions of this Treaty."

21 According to Arnull, "If the Court took a liberal approach on the question of the category of acts susceptible to review and the status of the European Parliament in annulment proceedings, its attitude to the standing of private parties has on the whole been more restrictive" in Anthony Arnull, The European Union and its Court of Justice (2nd edn, OuP, 2006) 69 See for the precise rules on standing before the CJEU also EU Chapter 7. 